\title{
CINEMA IN TIMES OF THE PANDEMIC COVID: MOVIES HELPING TO MODERATE EMOTIONS AND SUPPORTING THE HEALTH TEAM
}

\author{
Cine en tiempos de la pandemia del COVID: películas que ayudan a \\ moderar las emociones y apoyan al equipo de salud
}

\author{
Pablo G. BLASCO; Maria Auxiliadora C. DE BENEDETTO; Marcelo R. LEVITES; Graziela MORETO \\ SOBRAMFA - Educação Médica e Humanismo. (www.sobramfa.com.br) S. Paulo (Brazil). \\ Correo electrónico: pablogb@sobramfa.com.br
}

Received 13 July 2020;

Accepted 31 July 2020

Published: 29 January 2021

\begin{abstract}
The current COVID-19 pandemic emerges the need of taking care of the health team, not only physical, but also mental health. The crisis we are experiencing has a twofold component: on the one hand the biological threat and on the other to deal with anxiety, fear, and disordered emotions, which are a threat to mental balance and to maintain the serenity necessary to cope with such a great challenge. It is crucial to raise the morale of those who deal daily with this threat of unprecedented proportions. A discouraged doctor is an element of the crisis and causes insecurity in patients and families. SOBRAMFA - Medical Education and Humanism, has disseminated recommendations through short videos for helping professionals to maintain an objective view of the reality they are experiencing. Using cinema through movie clips from different films helps to clarify details of the commented recommendations. Sense of community, leadership, teamwork, holding the emotions on realistic basis, communication skills, educating through example, professionalism, objectivity and realism for redeeming the circumstances are the topics emphasized by the movie clips. Below we list some of the ethical and existential dilemmas as well as the corresponding movie scenes that can help with decisions.
\end{abstract}

Keywords: COVID-19; cinema; medical education; emotions. 


\section{Resumen}

La actual pandemia de COVID-19 coloca la necesidad de cuidar del equipo de salud, no solo física, sino también mentalmente. La crisis que estamos viviendo tiene un doble componente: por un lado, la amenaza biológica y, por otro, lidiar con la ansiedad, el miedo y las emociones desordenadas, que son una amenaza para el equilibrio mental y para mantener la serenidad necesaria para hacer frente a tan gran reto. Es crucial elevar la moral de quienes se enfrentan a diario con esta amenaza de proporciones sin precedentes. Un médico desanimado es un elemento de crisis y causa inseguridad en pacientes y familias. SOBRAMFA - Educación médica y humanismo, ha difundido recomendaciones a través de videos cortos para ayudar a los profesionales a mantener una visión objetiva de la realidad que están experimentando. El uso del cine a través de escenas de diferentes películas ayuda a aclarar los detalles de las recomendaciones comentadas. Sentido de comunidad, liderazgo, trabajo en equipo, mantener las emociones de forma realista, habilidades de comunicación, educación a través del ejemplo, profesionalismo, objetividad y realismo para redimir las circunstancias son los temas enfatizados por los clips de películas. A continuación, enumeramos algunos de los dilemas éticos y existenciales, así como las escenas de películas correspondientes que pueden ayudar con las decisiones.

Palabras clave: COVID-19; cine; educación médica; emociones.

\section{THE SITUATION AND THE CHALLENGES}

The current COVID-19 pandemic makes us live in a difficult and unprecedented time. With each passing day, the care of the health team itself is essential. Not only physical care, but also mental health. Or put more simply, it is crucial to raise the morale of those who deal daily with this threat of unprecedented proportions. A discouraged, pessimistic doctor, with no perspective is also an element of the crisis and that attitude causes insecurity in patients.

Family medicine, dealing with both the emotional and the scientific side of medicine on a daily basis, plays a central role in tackling this pandemic ${ }^{1}$. Seeking to collaborate in this sense, our private Institution of family practice physicians and educators in Brazil, SOBRAMFA - Medical Education and Humanism, has disseminated recommendations through short videos ${ }^{2}$ that help professionals to maintain an objective view of the reality they are experiencing. An excessive and disproportionate concern for the global problems that the world is facing, does not help - even hinders - each professional to take care of their own responsibilities, of the specific sector that they are in charge of at this moment.
In addition to helping with a realistic perspective, the videos address aspects of affective education and how to moderate emotions to help with the ethical decisions that daily practice entails.

\section{DEALING WITH EMOTIONS: THE HIDDEN THREAT}

The crisis we are experiencing has a twofold component: on the one hand, the biological threat of a new virus, with terrible consequences for population health, since we deal with something unknown. On the other hand, anxiety, fear, and disordered emotions are also a threat to mental balance and the serenity necessary to cope with such a great challenge.

A poem by Fernando Pessoa illuminates this reflection. The poet says: "Life is what we make of it / Travel is travelers / What we see is not what we see / but what we are" ${ }^{3}$. In other words: we filter reality through our emotions, through the way we are experiencing that reality. This explains the anguish and afflictions when we consider the reality of the scenario we have in our context with eyes, feelings and emotions amplified and deformed by the world panorama presented by the media. Therefore it is necessary to act - and feel - locally ${ }^{4}$, preventing global emotions. 
In medical practice, ethical dilemmas are often blurred by emotions: those of the patients and those of the professional who takes care of them. The universe of affectivity - feelings, emotions and passions - has been assuming an increasing role as a protagonist in the world of health education. The learners' emotions cannot be ignored in this process. Training human beings requires educating their affectivity, working with their emotions. Educating attitudes is more than offering theoretical concepts or simple training; it implies promoting reflection which facilitates the discovery of oneself and allows to extract from the intimate core of the human being a commitment to improve. How to do this in an agile, modern, understandable and effective way?

Humanities such as literature, music, cinema and narratives are a useful resource for educating emotions and promoting empathy, which is the cornerstone of medical professionalism and ethical behavior. The emotions that these experiences arouse must be transformed by reflection into experiences that generate attitudes capable of building ethical attitudes and building professionalism ${ }^{5}$.

\section{MOVIES HELPING TO MODERATE EMOTIONS:} SUPPORTING ETHICAL DECISIONS

The cinema, an educational resource used in medical education ${ }^{6,7}$ is included in these videos ${ }^{2}$. Using clips from different film scenes ${ }^{8}$, it helps to clarify details of the commented recommendations. Below we list some of the ethical and existential dilemmas as well as the corresponding movie scenes that can help with decisions.

You are not alone: feeling sense of community

The film I am legend ${ }^{9}$ goes straight to the point: ("if there is someone out there, I can help, you are not alone"). And then, the fight against reigning pessimism: ("if people who make this world worse never take a vacation, how am I going to take it?"). One cannot succumb to pessimism, nor be passively involved in all kinds of news that arrive indiscriminately. In addition to social distance as an epidemiological prevention resource, a healthy informational distance must be kept.

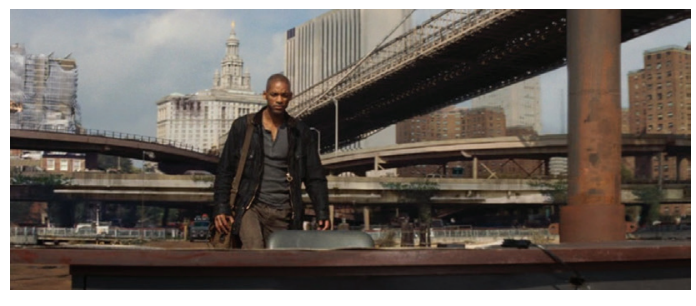

I am legend

Social isolation is recommended. Free museums and concerts are available on the Internet. Although cultural opportunities are unique we feel something is lacking. Aristotle said human beings are social animals, and what we lack is the experience of living the whole culture with someone, in society. At this point, the cinema illuminates the challenge: In The Shawshank Redemption ${ }^{10}$, the educated banker finds "Figaro's Wedding" record, and realizes that he can't enjoy Mozart's melody in solitude. He displays on loudspeakers and for a few minutes all those prisoners felt free. What we probably need is physical distance but maintaining social connectivity, as some authors recently point out ${ }^{11}$.

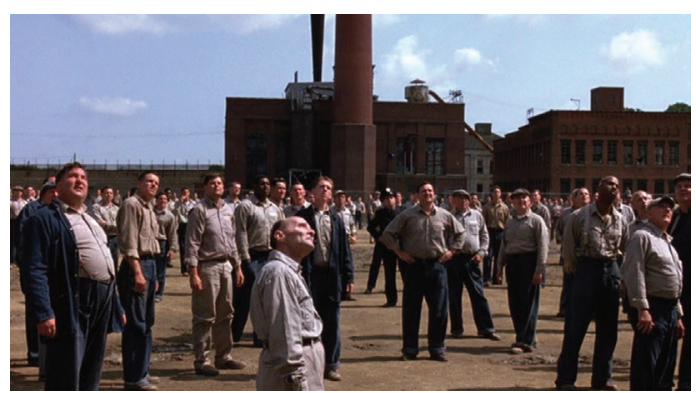

The Shawshank Redemption 


\section{Teamwork}

Teamwork is about keeping the team together and not tolerating the divisions that occur due to the natural tendency to look for culprits in times of crisis. Here is something that we witness daily, very well addressed in Ladder $49^{12}$ in the scene after the fireman's death: ("I just told a mother that her son died, and you argue in my house! We deal with this if we stay together, we learn the lesson, and we return to the vehicle and thus honour the dead colleague").

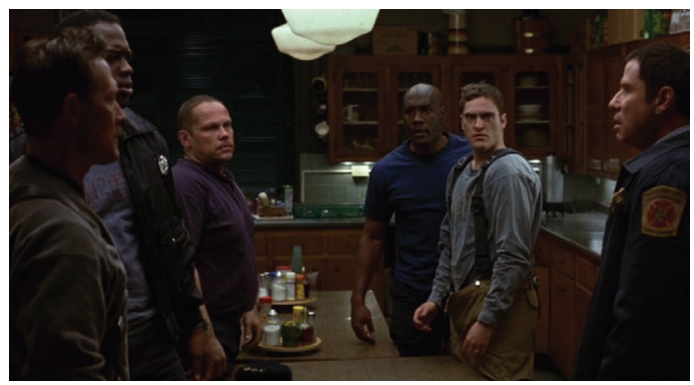

Ladder 49

The importance of the union that characterizes true teamwork stands out in Gladiator ${ }^{13}$ ("I do not know what will come out form these gates, but if we stay together, we will survive). Such an union is brilliantly depicted in the Spartacus ${ }^{14}$ scene ("I am Spartacus!"), in which the character is much more than a person: it is an idea that takes care of the team and promotes solidarity in times of crisis!

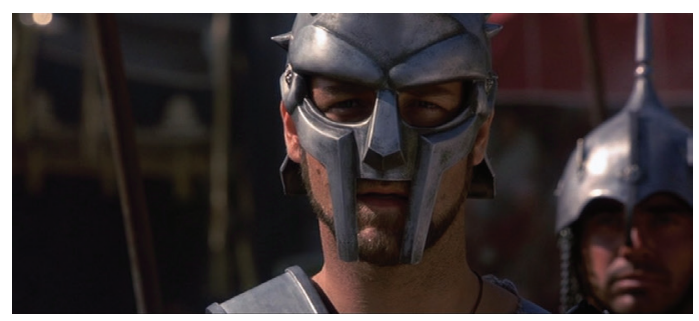

Gladiator

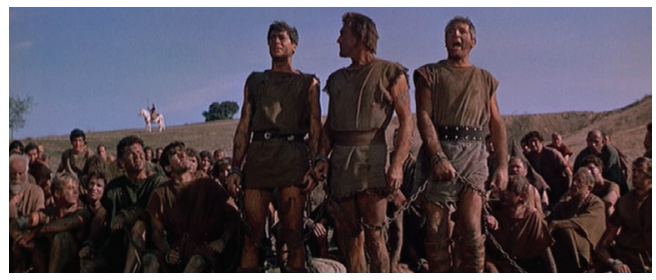

Spartacus

Holding your emotions on realistic basis: the ethical decision

The essential importance of patience and knowing how to wait represented in the scene of Braveheart ${ }^{15}$ in which William Wallace asks his soldiers to wait for the right moment to face the burden of enemy cavalry.

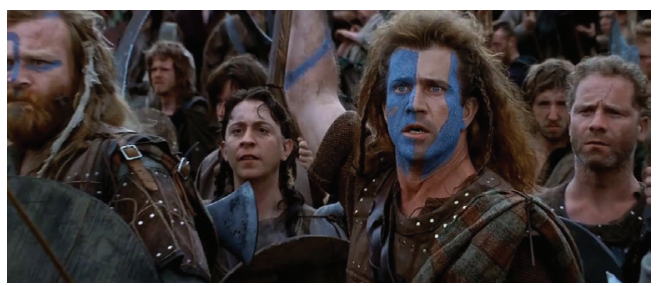

Braveheart

Running away from unnecessary anxieties, such as the healthy indifference of the Soviet spy in Bridge of Spies ${ }^{16}$ which contrasts with the disproportionate concern of the lawyer's son.

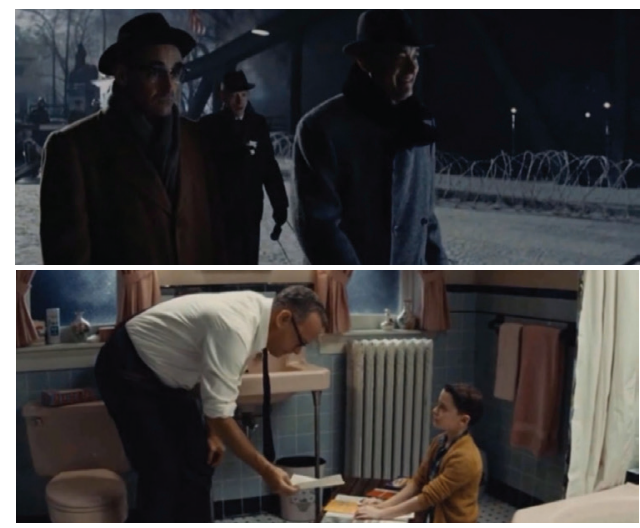

Bridge of Spies 
The two classic scenes from Casablanca ${ }^{17}$ remind us about the ethical doubt: (“I don't know what is right any longer; you will have to think for both of us"). Then at the airport: ("You will get on that plane, because otherwise you will regret it. Maybe not today, maybe not tomorrow, but someday and for the rest of your life"). As a student once said in a workshop: "the hard part is knowing how to get on the plane, nobody will do it for us".
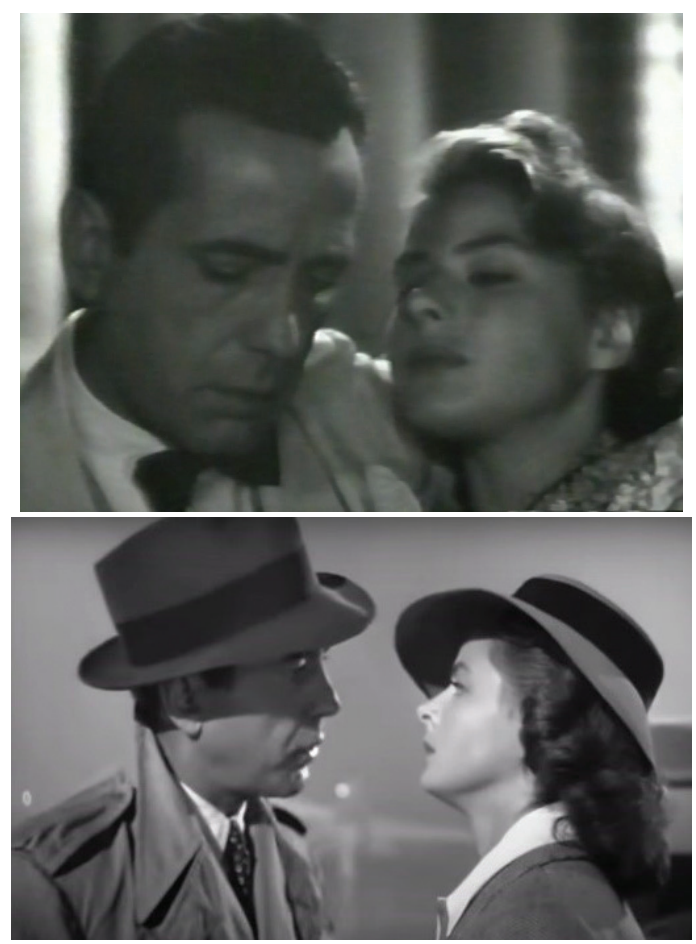

Casablanca

\section{Leadership follows self-control}

Immediately comes to mind the scene of Nelson Mandela in his cell on Robben Island Prison masterfully described in the movie Invictus $^{18}$ ("I am the captain of my soul, I am the lord of my destiny"). An example of leadership on himself, of whom spent 29 years in prison, without losing his nerves or focus on his mission.

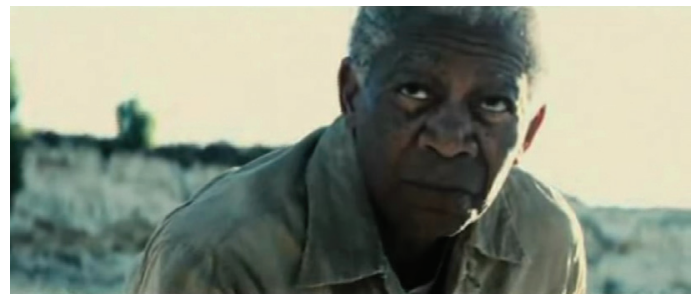

Invictus

Again, Bridge of Spies ${ }^{14}$, brings a clarifying scene in the soviet spy narrative: ("When I was small, your son's age, my father drew my attention to a man who visited us and who, apparently, had never done anything extraordinary. One day, the guards invaded our house, beat my father, my mother and this man too. And every time they hit him, he got up, over and over, without giving up. I think his insistence on getting up made the guards give up beating him, leaving him alone. I remember what they said: 'Stoikiy muzhik', which in Russian means something like steady man").

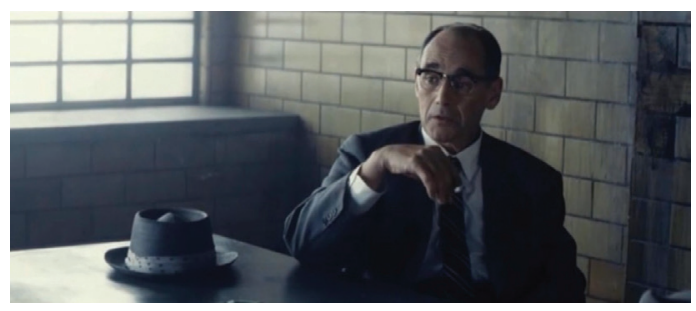

Bridge of Spies

Leading by example

In times of crisis, the absence of real leaders is perceived. Something analogous to what Ortega said about the pain of the phantom limb: feeling something that it should have and is missing. To set example is needed: "One of the most disconcerting mysteries of human psychology is that the fact of having an excellent ideal of life is not enough to live it, to put it into practice. How many companies proclaim their mission and values and then never happens. It is not enough 
to compose ideals, even with conviction. You need to get to the facts" $" 19$.

The scene from We were soldiers ${ }^{20}$ illustrates this point. The leader warns that the enemy is powerful and cannot promise to bring everyone back alive. But that he will be the first to set foot on the battlefield and the last to leave.

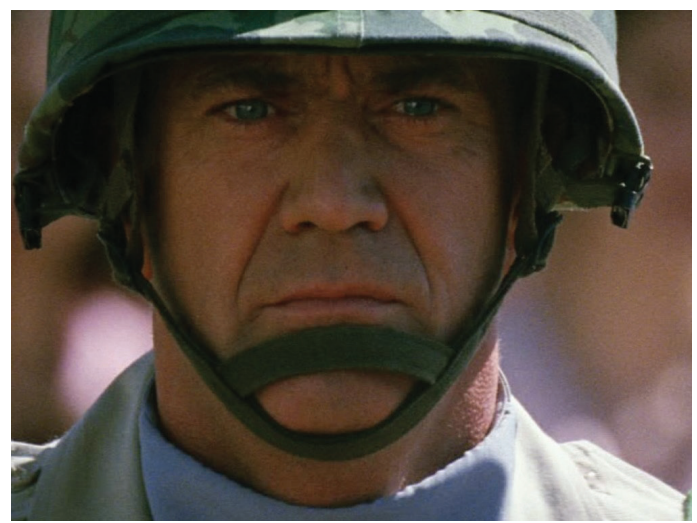

We Were Soldiers

"The affective leader is the one capable of managing expectations and producing confidence among those around him"21. It is worth remembering the Enemy at the Gates ${ }^{22}$ scene, where Khrushchev asks the generals what to do to motivate the frightened soldiers during the Battle of Stalingrad. Standard answers come up until someone points out: ("Give them hope. Men must believe in victory. They need pride and the will to fight. We need to create examples to be followed. We need heroes").

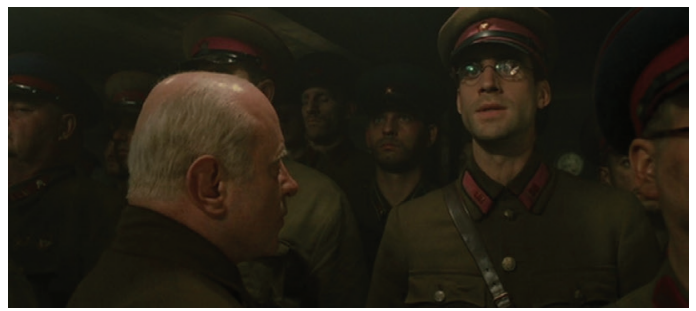

Enemy at the Gates
Leading by example necessarily invokes the final battle of The Last Samurai ${ }^{23}$. An unequal struggle, against modern weapons, where the Samurai's persistence ultimately yields a tribute from the enemy who, from winner, turns into admirer.

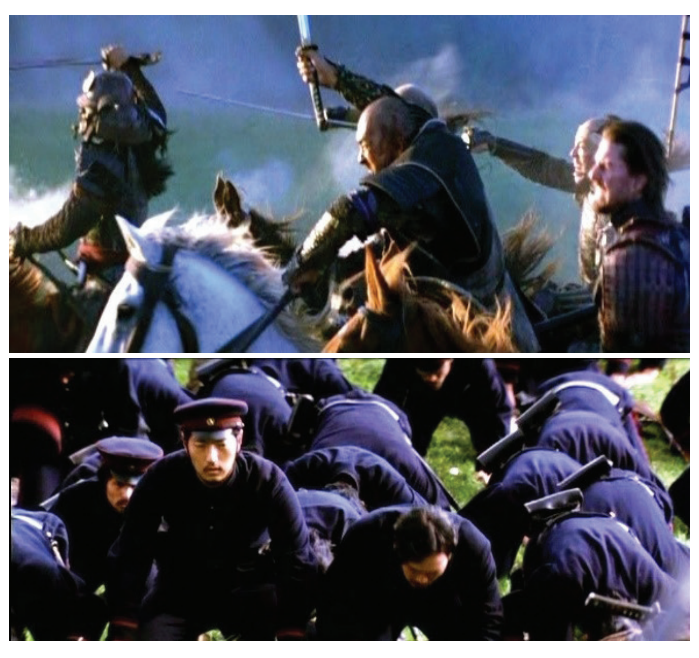

The Last Samurai

\section{The leader is an educator}

To set an example is needed, beside the wisdom of knowing how to wait. In K 19: The Widowmaker ${ }^{24}$ the admiral follows the advice of his subordinate: ("don't order, explain the situation, wait for the men to respond"). The responses of support with the command arrive little by little. The leader feels that he can make the decision.

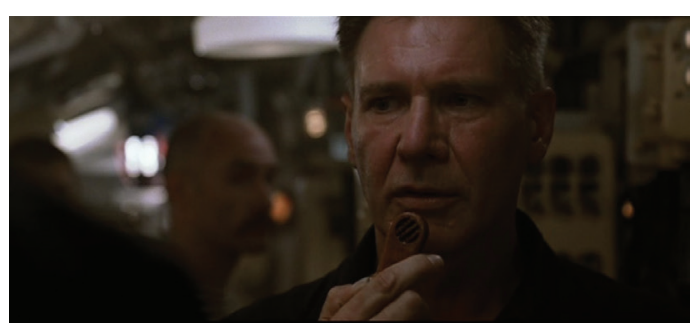

K 19: The Widowmaker 
To lead is to make people understand the situation, the risks, and let people freely embrace the commitment. This is what Glory ${ }^{25}$ tells us, a film that is poetry wrapped in blue uniforms and cannon smoke. Colonel Shaw exposes the risk to his regiment, the 54 of Massachusetts, integrated by black men, former slaves. ("If we fall into the hands of the enemy, we will be summarily shot. Whoever wants to leave, will be dismissed tomorrow"). Everyone stays and faces the difficulties, starting with the reduced salary, in which Shaw also makes a point of participating. In the final battle, Shaw asks for the honor of leading the attack, even though he knows that few will survive: ("There is more than rest in the battle. There is character, strength of heart").

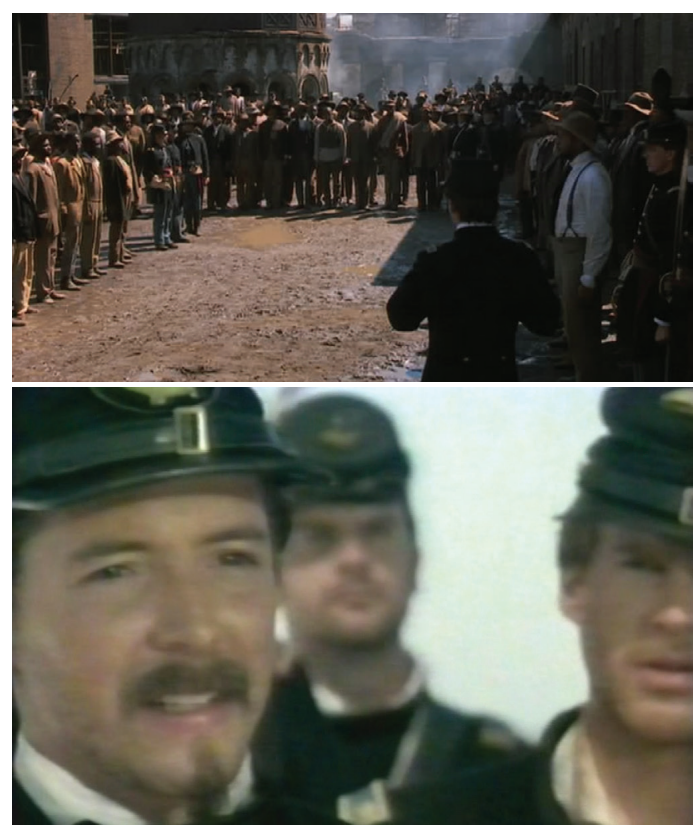

Glory

Saving Private Ryan ${ }^{26}$, an epic that exudes education. James Ryan does not want to return home despite having lost his brothers in the war: ("I will stay here with the brothers I have left"). Captain Miller - who was a professor in civilian life - is dying, and pronounces the definitive words: ("James, earn this"). Decades later, James Ryan goes to the cemetery and next to the captain's grave faces his commitment: ("Every day I think about what you said that day on the bridge. I tried to live my life the best I could. And I hope that at least at your eyes I earned what you did for me"). A striking example of leadership that educates, of lifelong learning.
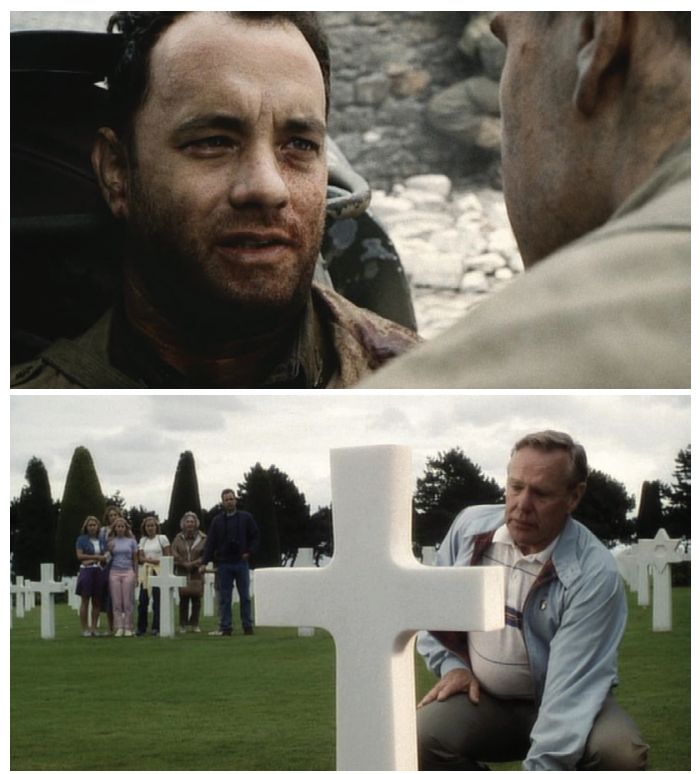

Saving Private Ryan

The art of communication: getting to know the interlocutor

We live in a connected world over which we have control. We spend hours exchanging messages, interconnected with the world in real time, we know everything and everyone. But we don't communicate and, consequently, we don't understand each other.

Arrival ${ }^{27}$ magnificently illustrates these shortcomings in communication. The dialogue we think we have is a fiction. We listen, but our focus is on putting our opinion, without a vital opening to what comes to us from the other, and to the 
way we see life and the world. We are shielded and avoiding to leave the comfort of our position.

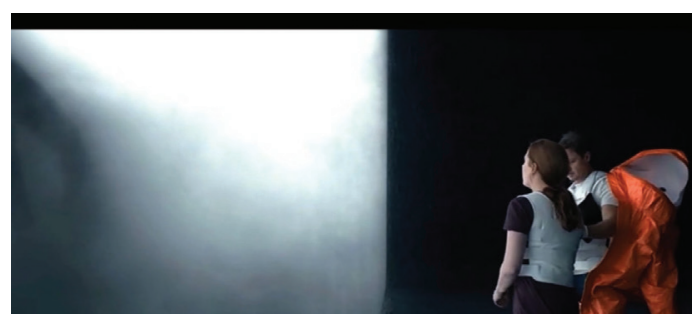

Arrival

Communicating implies knowing others, their history. "Before judging a person, spend three moons wearing their shoes. Outwardly, many lives can seem wrong, irrational, crazy. As long as we stick to the outside, it will be easy to misinterpret people and our relationship with them. Only by penetrating them, just walking three moons with their shoes, will we be able to understand their motivations, their feelings, which leads them to act in one way, and not in another. Understanding is born out of humility, not pride in knowing" 28 .

Amistad $^{29}$ illustrates magnificently this thought in the scene where the lawyer who defends the mutinous slaves asks the American politician for advice ("What is their story? Don't tell me they are Africans, we already know that. But who are they, what is their story?").

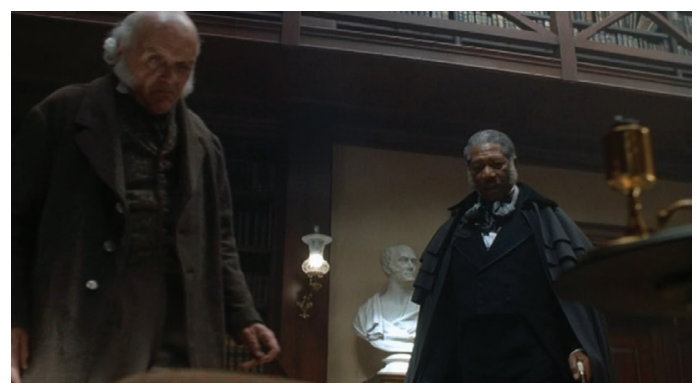

Amistad

Ortega warns of this humility: "to understand others, it is necessary to reconstruct their landscape and their world, and for that the focus of the gaze must be guided by the pupil of others" ${ }^{30}$. And he adds: "It is necessary to put yourself in tune, adjust the melodic tempo to the rhythm of the other's heart" ${ }^{\prime 31}$.

Melody and music that can be created when looking at each other, and not just the score of the guidelines. This aspect is very well illustrated in The Legend of $1900^{32}$ : ("How do you create this song? I look at people, I try to understand their inner world, and music emerges"). A wonderful example of Person-Centered- Music (evocating the Patient Centered care model)

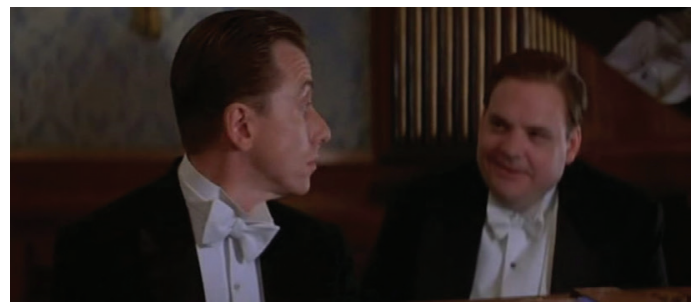

The Legend of 1900

Knowing that the science of communication is up to the professional, and that the patient does not have to have this competence. Learning to read between the lines, knowing how to listen even with an open heart and mind, without diagnostic urgencies or classificatory impulses. Analyze This $^{33}$ offers a good example, in the dialogue between the mafia boss and the psychiatrist who manages to guess what the patient does not have the courage to report explicitly.

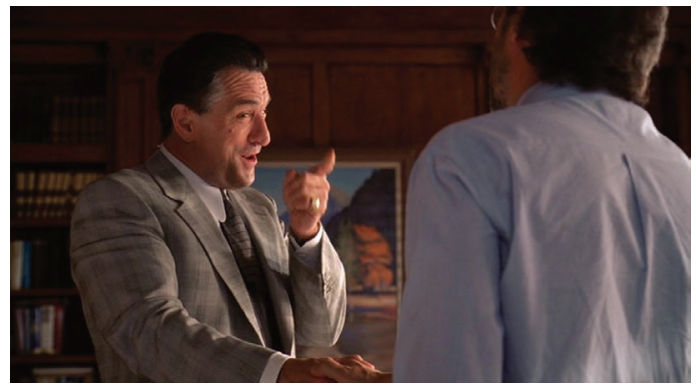

Analyze This 
Difficult patients and families or lack of professionalism?

The suffering that the disease implies - for the patient and the family - makes professionals to face situations where there are apparently challenged, and the system is questioned. Several scenes from John $\mathrm{Q}^{34}$ (A father willing to commit suicide in order to give his heart to his son who needs a transplant), situate the problem crudely.

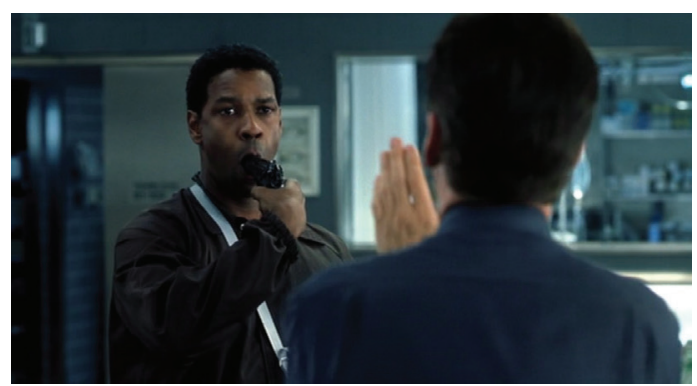

John Q

The ways to face the challenge always go through understanding and affection, which is a professional attitude, as it implies a sincere desire to help. An anthological scene from In the Name of the Father ${ }^{35}$ where the father, supposedly a pusillanimous one, calms his son's sterile revolutionary anxieties.

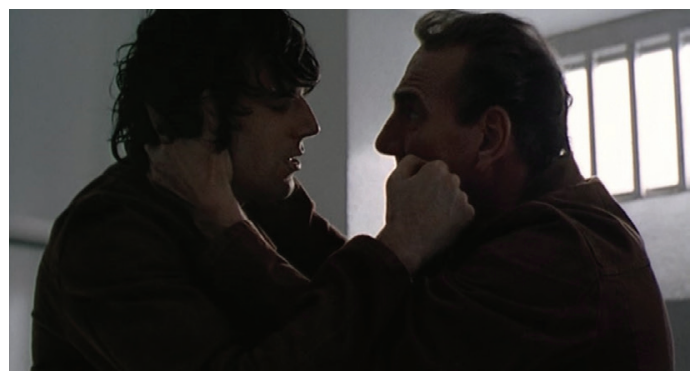

In the Name of the Father

A variant on the same theme offers us the scene of Blood Diamond ${ }^{36}$ where the father awakens his son's affective memory, transformed into a young terrorist through brainwashing. If the paternalistic model in medical practice is questioned because of the patient's autonomy, it is worth thinking if emulating the degree of dedication of a father who really loves does not offer a model to be followed. Affection and dedication that in no way compromise professionalism.

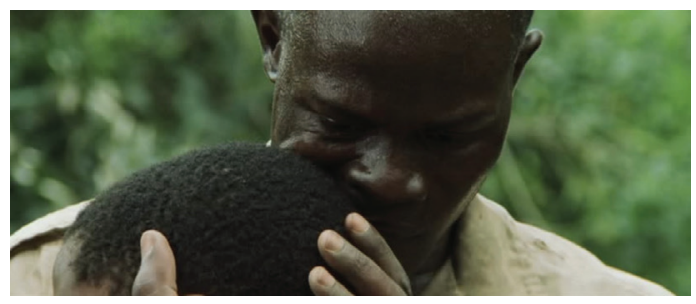

Blood Diamond

Dedication that surpasses technique, like the mirror lights in the scenes of Marvin's Room ${ }^{37}$, to calm the anxieties of a demented elder, managing to get a smile from him.

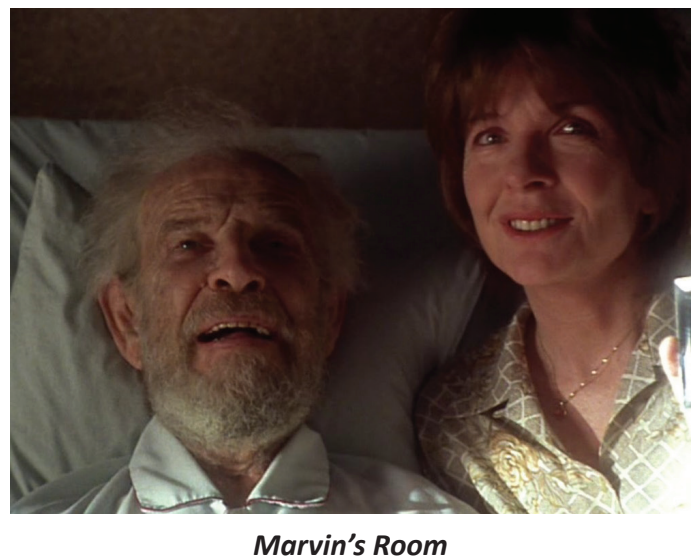

Redeeming the circumstances.

Circumstances challenge us, but cannot condition us. Impossible not to evoke at this point, Ortega y Gasset's reflections in his Meditations on Don Quixote ${ }^{38}$. To live what we have, in our conditions and circumstances. Hence 
the well-known phrase of the philosopher: "It is me and my circumstances, and if I do not save them, I do not save myself." Phrase often cited, but mostly incomplete. Circumstances are placed, in popular culture, as an excuse and not as a challenge to be saved, redeemed. For this reason, Ortega adds: "We have to search for our circumstances what is peculiar, the right place in the immense perspective of the world. Not dwell on fixed values, but conquer the right place among them in our individual lives. In short: the reabsorption of circumstances is the specific destiny of man." To redeem the circumstances, that's what it's all about in the midst of crisis.

And again the cinema appears to broaden the reflections. Peter Weir, the Australian director, is a specialist in "redeeming circumstances". Getting on the table in Dead Poet Society ${ }^{39}$, to gain other perspectives on reality. Or tie yourself to the ship - become one with your mission of freedom - in The Truman Show ${ }^{40}$, to face the tidal waves of slavery. Or overcome the loss of an arm, like in Master and Commander: The Far Side of the World ${ }^{41}$ having Admiral Nelson as role model: with one arm led the British squad to victory, and presides over the London landscape from the column in Trafalgar Square.

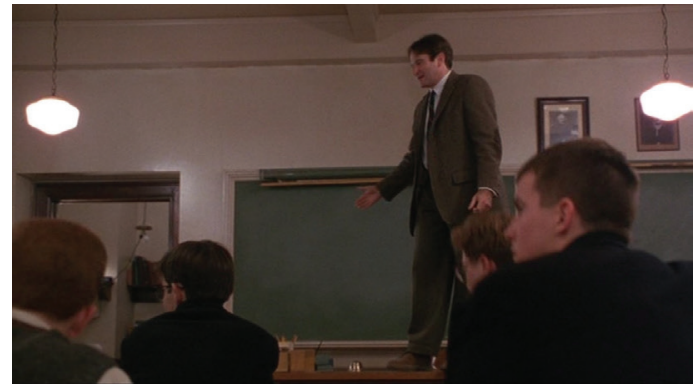

Dead Poet Society

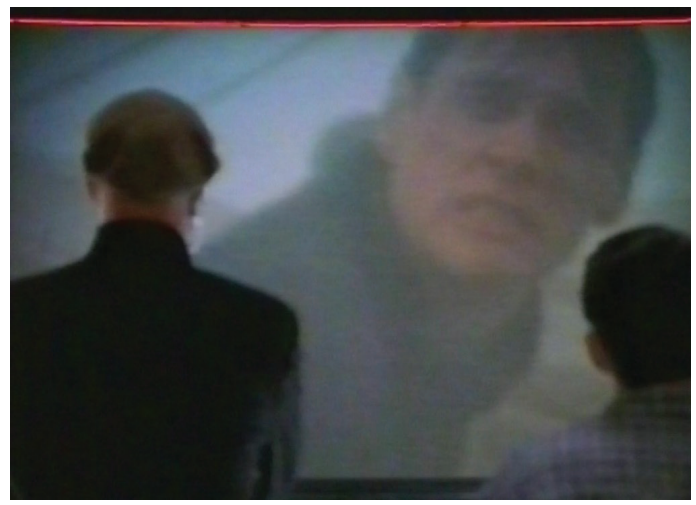

The Truman Show

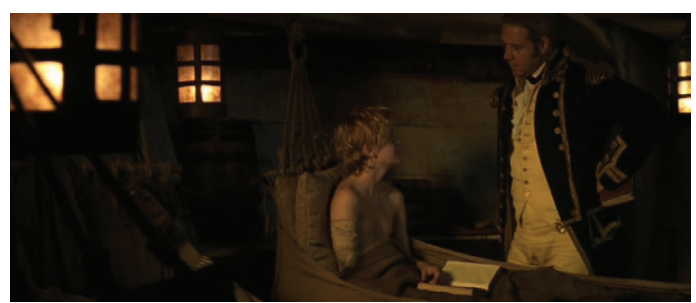

Master and Commander

OBJECTIVITY AND REALISM: D. QUIXOTE AT THE BOTTOM LINE

The toxic news that arrives daily through all the communication channels, saturates and depresses. Tragedies - which certainly exist are highlighted but conquests and overcoming are omitted. We see how the people around us - citizens, patients and, of course, health professionals - succumb to this bombardment. What we need is to pay attention to what we have at hand, without getting lost in dreams or fantasies. Or in chimeras and fears.

It is worth invoking D. Quixote again through Ortega's reflections ${ }^{38}:$ "The enchanters may well take my luck, but not the effort and the spirit. If we resist that inheritance and the environment imposes certain actions on us, it is because we try to base ourselves, only on ourselves, on the 


\section{CINEMA IN TIMES OF THE PANDEMIC COVID: MOVIES HELPING TO MODERATE EMOTIONS AND SUPPORTING THE HEALTH TEAM}

PABLO G. BLASCO; MARIA AUXILIADORA C. DE BENEDETTO; MARCELO R. LEVITES; GRAZIELA MORETO; MARCO AURELIO JANAUDIS

origin of our actions. When the hero wants, it is not the ancestors or the customs of the present who want something, but himself. Heroism consists precisely in this desire to be himself who he has to be".

\section{REFERENCES}

1. De Sutter A, Llor C, Maier M, Mallen C, Tatsioni A, van Weert $\mathrm{H}$, et al. Family medicine in times of 'COVID-19': A generalists' voice. Eur J Gen Pract. 2020; 26(1): 58-60.

2. González Blasco P. Humanismo Médico em tempos de crise. Vimeo [Internet]

3. Pessoa F. Mensagem. Rio de Janeiro: Nova Aguilar; 1976.

4. Haffajee RL, Mello MM. Thinking Globally, Acting Locally - The U.S. Response to COVID-19. N Engl J Med 2020; 382: e75

5. Benedetto MAC, Moreto G, Janaudis MA, Levites MR, Blasco PG. Educando as emoções para uma atuação ética: construindo o profissionalismo médico. RBM Rev Bras Med (Rio de Janeiro). 2014;71:15-24.

6. Alexander M, Lenahan P, Pavlov A. Cinemeducation: A comprehensive guide to using film in medical education. Oxford: Radcliffe Publishing; 2005

7. Blasco PG. Humanizando a Medicina: Uma Metodologia com o Cinema. São Paulo: Centro Universitário. São Camilo;2011.

8. Blasco PG, Moreto G, Roncoletta AFT, Levites MR, Janaudis MA. Using movie clips to foster learners' reflection: Improving Education in the Affective Domain. Fam Med 2006; 38(2) 94-6.

9. I Am Legend. (2007). [Internet]

10. The Shawshank Redemption. (1994) [Internet]

11. Bergman D, Bethell C, Gombojav N, Hassink S; Stange, K. Physical distancing with social connectedness. Ann Fam Med. 2020; 18(3):272-7.

12. Ladder 49 (2004). [Internet]

13. Gladiator (2000) [Internet]

14. Spartacus (1960) [Internet]
15. Braveheart (1995) [Internet]

16. Bridge of Spies (2015) [Internet]

17. Casablanca (1942) [Internet]

18. Invictus (2009) [Internet]

19. Sonnenfeld A. Liderazgo ético. Madrid: Encuentro; 2011.

20. We were soldiers (2002) [Internet]

21. Jovell A. Liderazgo Afectivo. Barcelona: Alienta Editorial; 2007.

22. Enemy at the Gates (2002) [Internet]

23. The Last Samurai (2003) [Internet]

24. K 19: The Widowmaker (2002) [Internet]

25. Glory (1989) [Internet]

26. Saving Private Ryan (1998) [Internet]

27. Arrival (2016) [Internet]

28. Tamaro S. Va' dove ti porta il cuore. Roma: Baldini \& Castoldi; 1994

29. Amistad (1997) [Internet]

30. Ortega y Gasset J. Notas de andar y ver. Madrid: Revista de Occidente. Alianza Editorial; 1988.

31. Ortega y Gasset, J. Estudios sobre el Amor. Madrid: Revista de Occidente; 1957.

32. The Legend of 1900 (1998) [Internet]

33. Analyze This (1999) [Internet]

34. John Q (2002) [Internet]

35. In the Name of the Father (1993) [Internet]

36. Blood Diamond (2006) [Internet]

37. Marvin's Room (1996) [Internet]

38. Ortega y Gasset, J. Meditaciones del Quijote. Madrid: Revista de Occidente. Alianza Editorial;1981.

39. Dead Poets Society (1989) [Internet]

40. The Truman Show (1998) [Internet]

41. Master and Commander: The Far Side of the World (2003) [Internet] 


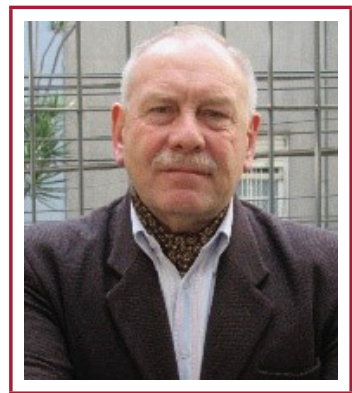

Pablo González Blasco. Médico y Doctor en Medicina, por la Facultad de Medicina de la Universidad de São Paulo, Brasil. Miembro fundador y actual Director Científico de SOBRAMFA- Educação Médica \& Humanismo. Autor de diversas publicaciones y trabajos presentados en congresos nacionales e internacionales, donde aborda los temas de Medicina de Familia, Educación Médica, Humanismo y Medicina, Educación de la Afectividad a través del Cine y de las Artes.

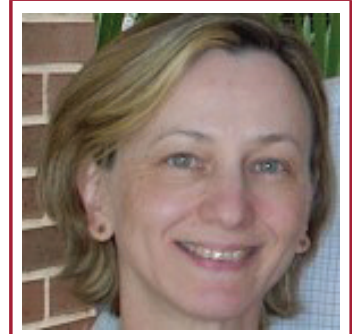

Maria Auxiliadora Craice De Benedetto. Médico y Doctor en Medicina por la Universidad Federal de São Paulo, Brasil. Directora de Publicaciones de SOBRAMFA- Educação Médica \& Humanismo. Autora de diversas publicaciones y trabajos presentados en congresos nacionales e internacionales, donde aborda los temas de Humanidades Médicas, Medicina Basada en Narrativas (Narrative Medicine), Literatura \& Medicina, Cuidados Paliativos, Educación Médica y Bioética.

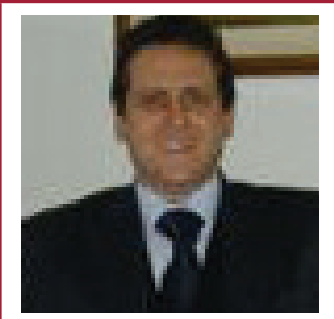

Marcelo R. Levites. Médico y Doctor en Medicina por la Facultad de Medicina de la Universidad de São Paulo, Brasil. Director Ejecutivo de SOBRAMFA- Educação Médica \& Humanismo. Autor de diversas publicaciones y trabajos presentados en congresos nacionales e internacionales, donde aborda los temas de Medicina de Familia, Educación Médica, Longevidad, Cuidados Paliativos y los desafíos de la Incertidumbre y del Burnout en estudiantes y profesionales de la salud.

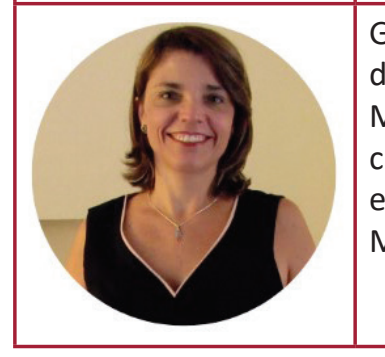

Graziela Moreto. Médico y Doctor en Medicina, por la Facultad de Medicina de la Universidad de São Paulo, Brasil. Directora de SOBRAMFA- Educação Médica \& Humanismo. Coordina los Programas de Formación y Cooperación Internacional. Autora de diversas publicaciones y trabajos presentados en congresos nacionales e internacionales, donde aborda los temas de Medicina de Familia, Educación Médica, Humanismo y Empatía. 